\title{
The Negative Impact of High Electricity Tariff on Consumers/End-Users in Some Developing Countries
}

\author{
${ }^{1}$ Boniface O. Anyaka, ${ }^{2}$ Chudi J. Edokobi \\ ${ }^{I}$ Department of Electrical Engineering, University of Nigeria Nsukka Enugu state Nigeria \\ ${ }^{2}$ Department of Electrical Engineering, University of Nigeria Nsukka Enugu State Nigeria
}

\begin{abstract}
The inability to put enabling facilities and technology in place which will enhance the exploitation of available resources (natural gas and hydro potentials) for power generation, transmission and distribution network are due to short-lived plan, age-long corruption, availability of faulty and insufficient components like transformers, bad management, negligence of vital issues, and low electricity tariff. These led to the incessant epileptic power supply in Nigeria. Efforts to maintain a substantial power generation capacity with stable transmission and distribution over a long period in Nigeria led to the deregulation of Nigeria power sector in November 31,2013, with the idea to allow private organizations to take over some aspects under public private partnership (PPP) agreement. The electricity tariff was increased in the process in order to make the sector attractive to the intended investors prior to the privatization and set platform of realizing every investment made by assuring constant power supply. This is part of the effort towards achievement of the Vision 20/2020 of the Federal Republic of Nigeria. The increased tariff has negative impact on the end-users since there is no significant increase in amount of power supply as promised to compliment the situation rather the existing capacity dropped drastically by more than half of what it used to be and resulted to frequent nationwide load shedding. This paper highlights the negative impact of the increased tariff to consumers and statistically analyzes the electric tariff in general.
\end{abstract}

Keywords: Negative impact, electricity tariff, price, gas flaring, climate change.

\section{Historical Background}

Electricity supply in Nigeria dates back to 1886 when two small generating sets were installed to serve the then Colony of Lagos. By an Act of Parliament in 1951, the Electricity Corporation of Nigeria (ECN) was established, and in 1962, the Niger Dams Authority (NDA) was also established for the development of Hydro Electric Power. However, a merger of the two was made in 1972 to form the National Electric power Authority (NEPA), which became Power holding Company of Nigeria (PHCN) in 2005 as a result of unbundling. [1] Lamentations about the poor performance of the power sector went down the drain despite purported huge financial investment due to corruption. Nigeria spent more than \$10 billion from 1999-2007 on the power sector without any positive results.[2] Weak institutional framework and governance failures induced gross inefficiency in production, distorted investment choices and demand patterns, high costs of operation, low return on investment and cost overruns encouraged widespread corruption in power sector.

The process of deregulation commenced in March 2005, as the Power Sector Reform Bill was signed into law, enabling private companies to participate in electricity generation, transmission, and distribution. The government separated PHCN into a Transmission Company of Nigeria (Transysco); six generating companies, ( Egbin Power Plc, Afam Power Plc, Kainji Hydro Electric Plc, Shiroro Hydro Electric Plc, Ughelli Power Plc, Sapele Power Plc); and eleven distribution firms, Kano Electricity Distribution Company, Kaduna Electricity Distribution Company Plc, Yola Electricity Distribution Company Plc, Enugu Electricity Distribution Company Plc, Abuja Electricity Distribution Company Plc, Ibadan Electricity Distribution Company Plc, Jos Electricity Distribution Company Plc, Eko Electricity Distribution Company Plc, Ikeja Electricity Distribution Company Plc, Port Harcourt Electricity Distribution Company Plc, Benin Electricity Distribution Company Plc, all of which were fully privatized and handed-over to the successful bidders November 31, 2013. [3]

\section{Existing Potentials for constant Power Generation in Nigeria Natural Gas}

Nigeria has about 176 trillion cubic feet (TcF) of natural gas reserve [1] [4][5]. In many of Nigeria's oil fields, the associated natural gas is often flared due to lack of the infrastructure needed to produce and market associated gas for electricity generation. According to Nigerian Petroleum Corporation, Nigeria flared about a third of its gross associated gas in 2010. Efforts should be made to develop the required infrastructure to harness the resources since $80 \%$ of our power generating plants is gas fired. Government should in addition implement zero gas flaring policies. Nigeria is the driving force behind the West Africa Power Pool (WAPP), which sells electricity to Benin and Niger while more than $50 \%$ of her populations are in total darkness. Nigeria supplies gas 
to the West African Gas Pipeline (WAGP) project which runs across Ghana, Benin and Togo; a case of chasing rats while the house is on fire. Paradoxically, the gas mentioned is mostly concentrated in the Niger Delta region where the issue of insecurity, oil theft and pipeline vandalism is rampant. The situation in Niger Delta region may not guarantee safe and steady supply of gas to meet the required target.

Hydro-electric power currently accounts for approximately 30 percent of the total electricity supply. There remains significant potential for additional hydro-electric power generation, possibly greater than 11,000 MW, using the country's overall hydropower resources. Current funding for clean energy is globally as the rate of ozone layer depletion as a result of carbon emission and other environmental factors in on increase. The government plans to develop around 4,800 MW of installed capacity by 2013, under the National Integrated Power Plants (NIPPs) but since privatization has taken effect private funding will be needed to reach the desired development of renewable energy capacity. Most of the power generation capacity is being built by foreign companies in partnership with Nigerian firms which any effort to re-coupe the capital investment within a short period amount to additional taxing of the electricity consumers. The Federal Ministry of Power identified ten dams suitable for hydro-electric power generation and government is currently in the process of assigning the hydro power components of the dams to private investors but how reliable will these dams be due to the effect of weather and climate change.[1][4][5]

\section{Coal}

Nigeria has a substantial amount of coal deposit that can fire a power generating plant to supply electricity to at least $15 \%$ of her population. Benue, Enugu and Ebonyi State deposits are enough to power 5 states. The nigercem a cement company in Nkalagu, Enugu State is being powered by coal and the technologies to reduce carbon emission have been improved.

With these and all other abundant renewable energy resources like availability of sunshine for solar, Nigeria shouldn't have been among the power deprived nation in the world if not corruption.

\section{Causes Of The Recent Nationwide Load Shedding}

Inadequate gas supply and flooding are big problems for Nigeria grid power supply even with the just concluded deregulation. If there is no frantic effort made to ameliorate the situation there will still be problems. As of January, 2014 the Geregu, Omotosho and Olorunsogo plants have available capacities of 414MW, $126 \mathrm{MW}$ and 252MW respectively but could only generate 143MW, 81.2MW and 164.7MW, respectively due to gas constraints. The Geregu and Omotosho National Integrated Power Project (NIPP) plants had available capacities of $435 \mathrm{MW}$ and 500MW but were only able to generate $60 \mathrm{MW}$ and $102.5 \mathrm{MW}$, respectively due to low gas pressure. The Sapele NIPP, with $250 \mathrm{MW}$ available capacity, was totally out due to gas constraints, loading problem and civil work on its basement. The 500MW Olorunsogo NIPP plant was also out due to gas constraints and maintenance after a commissioning test. The Alaoji plant with 880MW available capacity was down following a water injection test. The National Control Centre, Oshogbo lamented the inability of the Nigerian Gas Company to supply enough gas to it. The installed available capacity at Egbin Power Station was reduced to generating 703MW because of an ongoing high turbine rotor vibration rehabilitation work.[6]

Also, the Sapele, Delta and Afam IV-V power plants, had 120MW, 375MW and 75MW available capacities could only generate 68MW, 346MW and 50MW, respectively due to low lube oil pressure, faults and maintenance works. The Kainji Hydro Plant was totally out due to rehabilitation of its 1G5 unit and the 1G6 unit since December 6, 2013 and is expected back on December 31, 2014. The 1G7 unit was out on stator winding E/F, while the 1G8 unit was out on fault. The 1G9 unit at the Kainji plant was also out due to upper guide bearing temperature problem, while the $1 \mathrm{G} 10$ unit was said to be out due to thrust bearing temperature but available for station service. The 1G11 unit of the plant was shut down on emergency due to abnormal noise in the unit, while the 1G12 unit was out for rehabilitation. The Shiroro Hydro Plant installed capacity is 450MW but can only generate 300MW due to ongoing repairs and overhaul. Similarly, the Jebba Hydro Plant had 385.6MW but was only able to do 327MW due to ongoing maintenance and hence the nationwide load shedding. The impact of the load shedding was higher in the northern part of the country, due to voltage instability issues previously affecting power supply in that area. [6]

According to Gyoo Chull Yeom, "Gas is not coming, and without this, the power plants cannot operate optimally. Gas supply is very important to the Nigerian power sector because almost 80 per cent of the power plants in the country are gas-fired.

\section{Electricity pricing (Electricity Tariff)[7][8][9]}

Electricity pricing (sometimes referred to as electricity tariff or the price of electricity) varies widely from country to country due to many reasons. The price of power generation depends largely on the type and market price of the fuel used, government subsidies, industry regulation, and even local weather patterns. Electricity prices vary between countries and can even vary within a single region or distribution network of the 
same country. In standard regulated monopoly markets, electricity rates typically vary for residential, commercial, and industrial customers. Prices for any single class of electricity customer can also vary by timeof-day or by the capacity or nature of the supply circuit for industrial customers, single-phase or 3-phase, etc. A specific market allows real-time dynamic pricing, and a more recent option in limited markets to date as typically following the introduction of electronic metering (Pre-paid), prices can even vary between times of low and high electricity network demand. The actual electricity rate (cost per unit of electricity) that a customer pays can often be heavily dependent on customer charges, particularly for small customers (e.g. residential users).

\section{Global price comparison}

Now that the private sector has been invited to invest in power (in order to fill the huge investment gap that exists) it can only do so if it makes economic sense. In other words, the electricity business must be made profitable and sustainable. MYTO 1 attempted to make the sector profitable, but it failed to do so because certain projections were not realized and so the tariffs charged were neither sufficient to cover costs nor efficiently collected. The following table in figure 1, provides a snapshot comparison of MYTO 1 tariffs (in Naira per kilowatt hour) and tariffs charged in neighboring countries as at 2009: [10]

Figure 1: Regional Comparison of MYTO-1

\begin{tabular}{|l|l|l|l|l|l|l|}
\hline & Chad & Niger & Cameroun & Benin & Ghana & Nigeria \\
\hline $\begin{array}{l}\text { Social Tariff } \\
(100 \mathrm{kwh} / \text { month })\end{array}$ & 11.07 & 16.85 & 17.33 & 21.60 & 9.41 & $\mathbf{1 . 5 8}$ \\
\hline $\begin{array}{l}\text { Residential Tariff } \\
(600 \mathrm{kwh} / \text { month })\end{array}$ & 25.60 & 16.85 & 19.10 & 24.51 & 12.92 & $\mathbf{9 . 6 8}$ \\
\hline $\begin{array}{l}\text { Commercial } \\
\text { Tariff } \\
(1800 \mathrm{kwh} / \text { month })\end{array}$ & 26.75 & 20.52 & 23.55 & 24.00 & 21.92 & $\mathbf{9 . 6 6}$ \\
\hline
\end{tabular}

\section{Source: Union of Producers, Transporters and Distributers of Electric Power in Africa (UPDEA) [www.updea-africa.org][10]}

The table above shows that Nigeria has the lowest electricity tariff in West Africa by far. Therefore, even if a private investor has millions of dollars to invest in power; it would make more sense to invest in Cameroun or Ghana than to invest in Nigeria. [10]

The table below shows simple comparison of current electricity tariffs in some industrialized countries and territories around the world, expressed in US dollars. While it is useful to compare world electricity prices at a glance it does not take into account a number of significant factors which includes fluctuating international exchange rates, a country's individual purchasing power parity, government electricity subsidies or retail discounts that are often available in deregulated electricity markets

The price also differs from the source of the electricity. In the U.S. in 2002, the cost of electricity by different sources is listed below: Coal: 1-4 cents; Gas: 2.3-5.0 cents; Oil: 6-8 cents; Wind: 5-7 cents; Nuclear: 67 cents; Solar: 25-50 cents. However, electricity costs from renewable sources depend highly on the source availability, reaching the so-called grid parity in parts of the world where even conventional power plants based on fossil fuel are costly enough (i.e. transportation costs of diesel to isolated communities).

It is worth noting that the high cost of electricity in the Solomon Islands, as shown in the figure 2 table below, is primarily a result of the use of imported diesel fuel as the main source of fuel for electricity generators.

Figure 2: Global Electricity prize Comparison

\begin{tabular}{|c|c|c|c|}
\hline Country & US cents $\mathrm{kWh}$ & As of & Sources \\
\hline Nigeria & 2.58 to 16.55 & July 2,2013 & Naija Tech Guide \\
\hline Solomon Islands & 88 to 99 & January 2014 & $\begin{array}{l}\text { [SIEA new tariff's } \\
\text { residential business fuel price } \\
\text { adjusted] }\end{array}$ \\
\hline Australia & 22 to 39.80 & August 23,2012 & {$[8],[9]$ Lume Energy } \\
\hline Cambodia & 15.63 to 21.00 in Phnom Penh & February 28,2014 & $\begin{array}{l}\text { Electricity Authonty of } \\
\text { Cambodia }\end{array}$ \\
\hline Dubai & $\begin{array}{l}6.26 \text { to } 10.35 \text { (plus } 1.63 \text { fuel } \\
\text { surcharge) }\end{array}$ & November 2013 & DEWA \\
\hline Canada & $\begin{array}{l}6.52 \text { to } 11.69 \text { depending on time } \\
\text { of day plus transmission, } \\
\text { delivery, and other charges of } \\
\text { about } 3.75 / \mathrm{kWh}\end{array}$ & February 9,2014 & THES \\
\hline Germany & 36.25 & May 1,2013 & EEP \\
\hline Uruguay & 17.07 to 26.48 & February 11,2014 & UTE \\
\hline Egyt & $\begin{array}{l}0.7 \text { for the first } 50 \mathrm{kWh} / \mathrm{Month} \\
\text { to } 9.6\end{array}$ & March 13,2014 & EgyptERA \\
\hline United Kingdom & 20.0 & November 30,2012 & $E E P, E P$ \\
\hline United States & 8 to $17 ; 37^{888}$ & September 1,2012 & EIA \\
\hline
\end{tabular}

Source: Wikipedia.org [14] 


\section{Electricity Price Methodology in Nigeria [3][4]}

The methodology used in setting electricity prices in Nigeria has been ill-defined and opaque since the Nigerian electricity sector was established. Electricity was considered a public welfare service to be provided by the government. Therefore, the electricity price had traditionally been subsidized. Prior to the 2008 Multi-Year Tariff Order (MYTO), a uniform pricing structure was used in which the electricity tariff remained fixed for years despite a continuous rise in the price of natural gas. Interestingly, over 80 per cent of Nigeria's power is generated from gas. In February 2002 the National Electric Power Authority (NEPA) set average tariff from $\mathrm{N} 4.50 / \mathrm{kwh}$ to about N6/Kwh. Following that setting, the company still operated with monthly deficits of nearly $\mathrm{N} 2$ billion, which led to its inability to tackle the problems of inadequate and unreliable electricity service. Nigerian government approved electricity prices of between N4/Kwh and N6/Kwh for single-phase consumers; between N6/Kwh and N8/Kwh for industrial users; and between N8/Kwh and N12/Kwh for the highest demand users, but the cost of electricity production was N10 per Kwh. Owing to this, the Nigerian Electricity Regulatory Commission (NERC) was established to develop a new tariff regime based on industry revenue requirements. This led to the new tariff regime that took effect through a Multi-Year Tariff Order (MYTO) in 2008.[3]

The Building Blocks approach to electricity pricing of transmission and distribution services under MYTO-1 was mainly aimed at providing the industry with a stable and cost-effective pricing structure to guarantee a modest return on investment for efficient industry operators and capital recovery for replacement of fixed assets. The MYTO-1 employed the efficient new entrant model for pricing and the Long Run Marginal Cost (LRMC) method was adopted in determining the unit price of an efficient plant. The LRMC Method calculates the full life cycle cost of the most efficient new entrant generator considering current costs of plant and equipment, return on capital, operation, maintenance and fuel costs, etc. Its advantage is that it has its basis in economic theory and encourages new investment to enhance capacity whilst striving to maintain the lowest cost of generation which the which kept increasing due to scarcity of fuel steadily at the target points. It aims at providing a reasonably efficient price as it is set at the lowest cost of a new entrant and should help to keep costs and tariffs at a minimum.

The 2008 MYTO set tariffs for electricity consumers for a five-year time period, while providing a 15year projection on the evolution of tariffs with time. The new tariff regime also provided incentives for reducing technical and non-technical losses, and signals for suppliers to invest more and consumers to adjust their consumption style efficiently. Tariffs for the initial five years, ranged from N9 to N11.50 per Kwh with an average of N10 per Kwh. Thus, the average electricity price which had stood at N6 per Kwh was increased substantially. Owing to this marked tariff increase, the Federal government designed a strategy that allows for a gradual rise in the price over four years (2008-2011) but without an increase in the first year; increases then occurring in years 2,3 and 4 . The tariff would become fully effective in the fourth year, 2011. In order to keep the sector financially viable, the government closed the gap between the required tariff and what consumers were actually billed. Unlike the previous uniform pricing regime, only the most needy tariff classes would enjoy a subsidy. The gradual removal of the subsidy is expected to reduce the burden on consumers while allowing them to adjust to the new price. The exit of the Federal government subsidy would occur when power availability rises sufficiently to enable a further rebalancing of the tariff.

In addition, the NERC provided different pricing options for arriving at tariffs to power generators. The MYTO model was designed to be applicable to all industry participants and end users and incorporate major and minor reviews of the electricity tariffs. Four variables considered in the minor reviews are the inflation rate, gas prices, foreign exchange rates and actual daily generation capacity while a comprehensive review and overhaul of all the assumptions in the MYTO model are considered in the major review. The major review gave room for evaluating the methodology, adding inputs to the existing models, incorporating Feed-in-Tariffs (FITs) for renewable energy and developing tariffs for coal generation among stakeholders. The assumptions reviewed include available generation capacity; forecast of electricity demand; expansion of the transmission and distribution networks; capital expenditure; operating costs; fuel costs; interest rates; weighted average cost of capital; revenue collection efficiencies; and subsidies, etc.

\section{Earlier Challenges in MYTO-1}

The changes in gas prices and the foreign exchange rate employed in the MYTO model made the offers unattractive to prospective participants. Also, the inability to consider the use of alternative energy sources such as coal, wind and solar, etc in the generation of electricity as many investors would intended to enter the market using other sources of fuel for generating electricity. However, its major disadvantage is that it fails to consider and addressed the different conditions being faced by the new or existing generators. As a result of these, NERC carried out a major review of the Tariff Order and came out with MYTO-2 in 2012. 


\section{MYTO $2[11]$}

MYTO-2 was designed for the period 1st June 2012 to 31st May 2017 with effect from May 31, 2012. The MYTO-2 introduced a wider review scope compared to the 2008 MYTO-1. For instance, material variation was incorporated into the MYTO-2 which is defined as a price variation of plus or minus five per cent $(+/-5 \%)$ in any of the above mentioned elements (inflation, exchange rate etc.). In addition, its regulatory model was based on data obtained from market participants. Industry costs and tariffs developed in its financial model are formulated from estimates and forecasts supplied by the participants and establishments in the industry.

A bi-annual minor review was considered in the new MYTO-2 and some changes were also effective which include flexibility in wholesale generation pricing and the consideration of other fuel types such as coal. In addition, the MYTO-2 created fourteen different classes of customers who would pay different rates according to their class. This pricing regime discouraged the entry of profit oriented private investors in addition to the absence of enabling legislation to back private investment in such sensitive area. There is need for appropriate policy to institute transparency in tariff determination and provide stability and predictability in electricity pricing.

\section{The Effects of high Tariff in Nigeria}

Government takes charge of the bulk of expenditures accrue in generation, transmission and distribution of grid power supply in Nigeria with the cost of running standby generators in her establishments. Since independence, the power sector in Nigeria has been run as a public welfare service rather than a profitable business. Sustaining any public service depends on political commitment and public funding. In Nigeria, unreliable political will has led to inadequate funding and multiple inefficiencies in the system. The graph below shows the pattern of investment experienced: [10]

\section{Figure 3: Nigeria Electricity Funding Chart by Government 1974-2005}

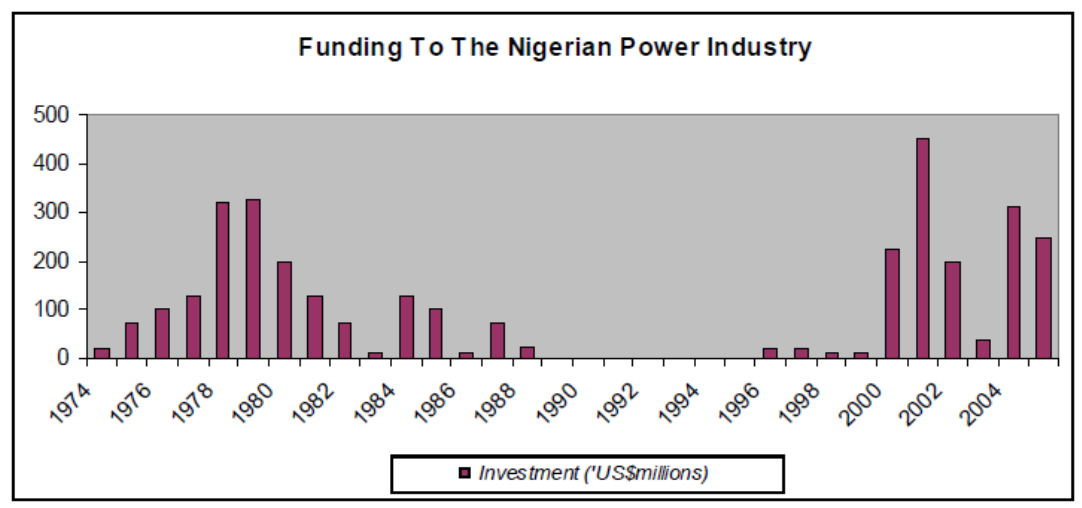

Source: Ministry of Power

What is clear from the graph is that the sector is still trying to recover from a pattern of underfunding that stretches back over 3 decades.[2]

Deregulation has been completed in Nigeria and tariff is increased as subsidy payment by government is no more as attentions are directed toward other pressing needs like Education, Agriculture and Health. Strategies to recoup every investment made were already in place; example pre-paid metering. Consumers pay more now but power supply has not improved owing to some of the factors earlier discussed. Now fuel to run generator is scarce and costly which resulted to high cost of production of goods and services. And the question is what is happening in power sector? There is a fixed charge of N23.89k per day which every consumer pays whether there is power supply or not. A scenario occurred which translated what is obtainable nationwide about nature of power supply. It is where a consumer purchased N1500 worth of unit for electricity in residential apartment in Gwgwalada, Abuja; after deduction of the fixed amount of N716.70k per 30 days, a credit unit of $71.2 \mathrm{kwh}$ was left which lasted six months before it finished due poor power supply. The N4300.20k fixed charges accumulated for six months must be paid before next recharge. This type of scenario is obtainable nationwide and it cripples trade of any organization that do not have alternative means of sustenance. Every business that is running with standby generator made little or no profit and stand the chance of losing customers. The increase in electricity tariff affect end-users in many factors as narrated below:

\section{Corruption}

It is truth that there is nowhere in world where electricity is cheap. The investment is capital intensive starting from installation to day to day operation to ensure reliability. The problem is that it is not available when needed and as demanded. The demand is more than the supply because the capacity functioning from the 
installed capacity is too low to carry the entire population. Nigerians are less serious about applying energy saving measures like switching-off lights when not in use as that would help to reduce the cost in principle by using less power consuming appliances. Some rather engaged in different nefarious to avert spending money which were narrated below.

In the case of grid power supply some corrupt electricity workers connives with consumers and tampers with metering devices in order to reduce the amount payable for power consumed. These are in many ways. As narrated below

They disrupt the meter settings especially pre-paid meters and compel owners to come and report for a fault, so that an approval for a temporary direct supply could be approved and no amount is paid for that transition period except greasing the hands of the architects. Any token generated is kept on hold for quite a long time as far as the benefactor is cooperating.

Another method of corruption is that of bye passing metering point Heavy electricity consuming appliances like cooker, air conditioners, freezers, etc. are bye passed to avoid paying more bills. Where pole mounted transformers are used, some lines were illegally created for such dubious activities. All these negative attributes were as a result of increased tariff in the sector without power supply and cogent effort to harness the available potentials like natural gas that can guarantee constant generation. On this note more efforts are required from the government to block illegal connections by promulgation of law with imprisonment as penalty for defaulters. Also the Council for the Regulation of Engineering (COREN) should be proactive in ensuring that only registered engineers should handle electrical works. The new investors must device a measure to fishout all the corrupt personnel they inherited from PHCN in order not to transfer their manipulative techniques to the new arrangement otherwise a total collapse will be imminent.

\section{Inflation}

Businesses thrive in areas where there is affordable and steady electricity. One of the important factors used to rate a country is the GDP which depends on economic productivity. Economic growth measured based on the number of industries, business organizations, rate of unemployment, amount of output based on what the country is able to generate or produce and services that can be easily translate into liquid cash. Absence of some of these could subject a country to full dependent on other countries. In Nigeria and other developing countries, electricity supply has been subsidized by government since colonial days and with that consumers do not take the issue of tariff serious. There is expectation of profit in every business investment but the case is different in Nigeria prior to the deregulation of power sector in 2012. The partial increase in the tariff is affecting has induced some percentage of inflation in the system. The high cost of fuel, increase from N4.50k to N11 and frequent outage due to a drop in the generation has forced companies to depend solely on standby generators. With these, the price of goods and services has escalated resulting to inflation. In 2011, the government reviewed the minimum wage of workers to $18 \%$ of what it used to be but with the current situation, additional increment is necessary.

\section{Exodus or shut down of firms}

The idea of deregulation was to bring in private investors both indigenous and multi-nationals to help in management of our power sector and as well create enabling ground for investors in many other businesses. This will boost the country's economy and create jobs. The contrary is the case based on the latest happenings. A lot of firms have left the country while some was shut down due to frustration of poor power supply and high electricity tariff. Many other firms incur deficit on daily bases due to damages caused to either machines or materials by frequent outages. Michelin and Dunlop are household firms in the tyre production in Nigeria with staff strength of not less than 5,000 Nigerians combined left to neighboring countries Ghana and South Africa respectively. The bulk products of these countries are still being used in Nigeria as statistics shows that the number of cars used in Ghana and South Africa combined are not up to what is being used only in south-west region of Nigeria. The market, production tax and employment creation which would have taken place here has gone to other countries.

\section{Unemployment}

The increase in electricity tariff contributed significantly to the rate of unemployment in the country in many ways. The increase in tariff and low electricity put the production industries on the survival of the fittest. Some individuals rely on loan to carry out their business. Failure to service such may lead to collapse. Many on the streets searching for jobs are victims of company liquidation. If power is stable, available and affordable, the issue of unemployment would have been a thing of the past. Many of unemployed persons in Nigeria are creative and would have been self-employed if power supply is constant and tariffs were not low 


\section{Health}

Increase in electricity tariff has caused many deaths indirectly. Due to the usual epileptic supply of power and high cost of fuel hospital services are expensive in Nigeria. There are cases where operations were obstructed due to sudden out age or lack of fuel to keep a generator running. Remember electricity tariff is not limited to the amount paid to power companies but also what is paid to generate electricity individually. These and money for maintenance are what made the electricity price called tariff. In order for a hospital to maintain integrity and minimize the number of casualties, its power supply must remain constantly on. Sensitive areas like theatre, radiology lab and mortuary need steady power supply which is possible only the use of a backup generator with high cost of fuel resulted to high bills. Many sick persons who cannot afford hospital died at home while the rich travel overseas for checkup.

\section{Sabotage}

High electricity tariff in fast developing country like Nigeria can be as sabotage by some developed countries. Nigeria is made up of many ethnic groups and wears tribal sentiments when it comes to national issues. These tendencies usually blindfold our leaders in taking vital decisions as one nation. No nation can cross the stage we are now with the help of other nation. Regional collaborations are necessary but not in areas of competition. $70 \%$ of household appliances manufactured in China and Europe are consumed developing countries and that increased the gross domestic product of these enabling them to maintain the status 'developed' countries. If the stability is achieved and fuel prices dropped in Nigeria and other developing countries, the table will turn round. Countries like China and India were able to break the shackles when they launched operation do it yourself. The issue of gas flaring wouldn't have come up if Nigeria is part of United State of America. Shell and other oil exploration companies in Nigeria knew how well to package these gasses to our power stations if they really have our interest at heart. High electricity tariff indirectly masterminded by developed has grounded consumers businesses in Nigeria thereby subjected youths who would have been participating in nation building to errand runners in Europe, America and Asia countries as traders.

\section{Agriculture}

About $60 \%$ of Nigeria populations are farmers that live in rural areas and needed electricity to process and preserve their produce. The cost of distribution and transmission of electricity to rural areas are enormous due to high losses involved. With the rate of power supply recently and high tariff, little or no meaningful amount of electricity is witnessed in rural areas. This affected the supply of food in the market as there is drop in food preservation and processing. It is not only affected the country's gross domestic product GDP but also the individual farmer whose only sustenance is based on agriculture. The yearly food supply to urban areas has dropped as a result of this forcing government to join in importation of commodities like rice and beans which can as well grow to any quantity here.

\section{Conclusion}

Power supply system in developing countries are characterized by issues ranging from instability, unreliability, corruption and high cost of generation, transmission and distribution. In Nigeria, the inability to put in place the necessary technology required to harness all the abundant resources like natural gas, hydro potentials and numerous renewable energy sources for constant power generation have resulted to the recent backwardness in development. Inflation, unemployment and many other negative vices have sky-rocketed with the increase in electricity tariff prior to deregulation. Several continuous outages in the past have forced many industries to close down or relocate to other countries and these hindered economic growth and advancement of the country.

Government should do more by providing all the necessary assistance to the successful investors (beneficiaries) in the deregulation exercise to enable them do their part and make power available for Nigerians at affordable price. This will create opportunities for development and create employment as idle mind is a devil workshop. Therefore machineries have to be in place to tackle the problems and difficulties discussed as they affect consumers so as to avoid total collapse.

\section{References}

[1]. A.S. Sambo, B. Garba, I. H. Zarma and M. M. Gaji: Electricity Generation and the Present Challenges in the Nigerian Power Sector Energy Commission of Nigeria, Abuja-Nigeria

[2]. E. Alike: How the Energy Sector Fared: THISDAY newspaper published, 12.15.2008 pages 34-35

[3]. S. L. Bello: Evaluating the Methodology of Setting Electricity Prices in Nigeria; Journal of International Association of Energy Economics

[4]. G. N. Ofoegbu and S. E. Emengini. : Recovery of Cost of Electricity Supply in the Nigerian Power Sector; University Of Nigeria, Enugu Campus, Enugu State, Nigeria

[5]. A. Iwayemi: Investment in Electricity Generation and Transmission in Nigeria: Issues and Options Journal of International association of Energy economics 
[6]. www.punchng.com/business/business-economy/power-nigeria-loses

[7]. www.premiumtimesng.com/news/153565

[8]. www.punchng.com/business

[9]. www.wikipedia.org

[10]. M. Wakil: Electricity-Prices-Are-Rising, NERC

[11]. NERC and PHCN successor companies 2012

[12]. Nigeria at a Glance wikipedia.org/wiki/Nigerian_Electricity_Regulatory_Commission-Electricity 